
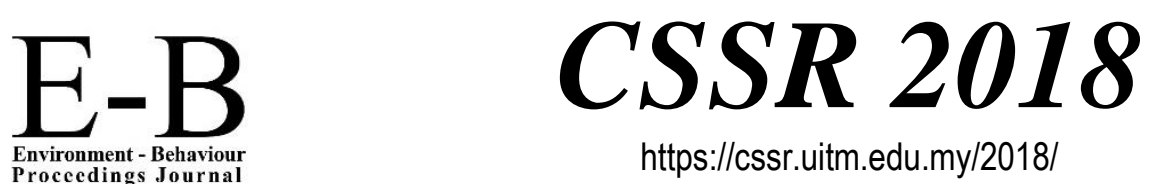

https://cssr.uitm.edu.my/2018/

5th International Conference on Science and Social Research Le Meridien Kota Kinabalu Hotel, 5 - 6 December 2018

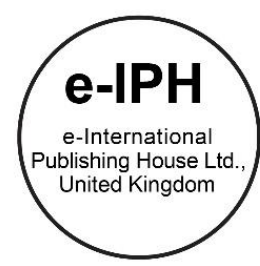

\title{
The Kayans: \\ Ontology of their tattoos and its meanings
}

\author{
Ruslan Abdul Rahim¹, Royer Wan², \\ ${ }^{1}$ Faculty oc Art \& Design, Universiti Teknologi MARA, 40450 Shah Alam, Selangor Malaysia \\ ${ }^{2}$ Tunku Abdul Rahman University College (TARUC), 53300 Kuala Lumpur, Wilayah Persekutuan Kuala Lumpur, Malaysia \\ ruslan@uitm.edu.my, royerwan@tarc.edu.my \\ Tel: 006-0122395511
}

\begin{abstract}
In Malaysia, the Kayans are just a minority group and have extensive traditional tattoos among the women folks. Anthropologists credited them as the pioneer of exquisite tattoos. The other tribes in Borneo got inspirations for their own body of art. This expansion of existing study attempts to make sense of the motifs and to address the intrinsic and extrinsic meanings of tattoo motifs and relate to their lives. Interviews among tattooed Kayan women folk provide the first-hand information about the implications of tattoos. The perspective of visual semiotics and semantics analysis ultimately shed light on the distant past.
\end{abstract}

Keywords: Kayan, Tattoo, Meaning, Motifs

eISSN: 2398-4287@ 2020. The Authors. Published for AMER ABRA cE-Bsby e-International Publishing House, Ltd., UK. This is an open access article under the CC BYNC-ND license (http://creativecommons.org/licenses/by-nc-nd/4.0). Peer-review under responsibility of AMER (Association of Malaysian Environment-Behaviour Researchers), ABRA (Association of Behavioural Researchers on Asians) and cE-Bs (Centre for Environment-Behaviour Studies), Faculty of Architecture, Planning \& Surveying, Universiti Teknologi MARA, Malaysia. DOI: https://doi.org/10.21834/ebpj.v5iSI3.2573

\subsection{Introduction}

In Malaysia, ethnic minority Kayan in Sarawak is known to have the most extensive traditional tattoo on the body; particularly women. Hose and McDougall (1912) in their book credited them as "the most and the best-tattooed tribe in Borneo, and it is to them that most of the other tribes in Borneo owe their knowledge of tattoo and the majority of designs" (p. 246). The rectified of the fact that the Kayans were the expert in tattoos. For them, the marking is their ties to their heritage (Ongie, 2012; Wong (as cited in Yuji, 2011)) and cultural identity (Mashman, 1989). Hence, they are very proud of their tattoos.

\subsection{Literature Review}

It was reported that there were approximately 15,000 Kayans in Baram basin (Marudi District Office, 2012) and another 10,000 in Belaga basin (Yussop, 2012). They are also synonymous with the term Orang Ulu; a term first introduced in Orang Ulu Customary Code of Fine (1950) published by Majlis Adat Istiadat Sarawak (Jalong, 2001, p. 4; Bibi, et al., 2009). The Kayan women covered themselves with a "complicated serial designs over the whole forearms, the backs of the hands, on the whole of the thighs to below the knees, and on the feet" (Hose and McDougall, 1912). This practice, however, was exclusively for the adult females only; never the

eISSN: 2398-4287@ 2020. The Authors. Published for AMER ABRA cE-Bsby e-International Publishing House, Ltd., UK. This is an open access article under the CC BYNC-ND license (http://creativecommons. org/licenses/by-nc-nd/4.0). Peer-review under responsibility of AMER (Association of Malaysian Environment-Behaviour Researchers), ABRA (Association of Behavioural Researchers on Asians) and CE-Bs (Centre for Environment-Behaviour Studies), Faculty of Architecture, Planning \& Surveying, Universiti Teknologi MARA, Malaysia. DOI: https://doi.org/10.21834/ebpj.v5iSI3.2574 
men. In the olden days, tattooing amongst girl was common; every girl wanted to be tattooed (Hose, 1926; Lim, 1991). The design given by the artist was according to their social standing (Hose, 1926; Lim, 1991; Payne et al., 1994). Getting the tattoo was also to mark a girl's pubescence and her readiness to be an adult. Withstanding the pain was a source of pride to them. Failure to complete tattoo would be labelled a coward (Lim, 1991). According to the old Kayan belief (Hose and McDougall, 1912), they believed that their tattoos would be torches in the afterworld (Krutak, 2006b). A completely tattooed woman would have the privilege to bathe in the mythical river Telang Julan and be able to pick valuable articles in that river. Those without tattoo would remain in the dark.

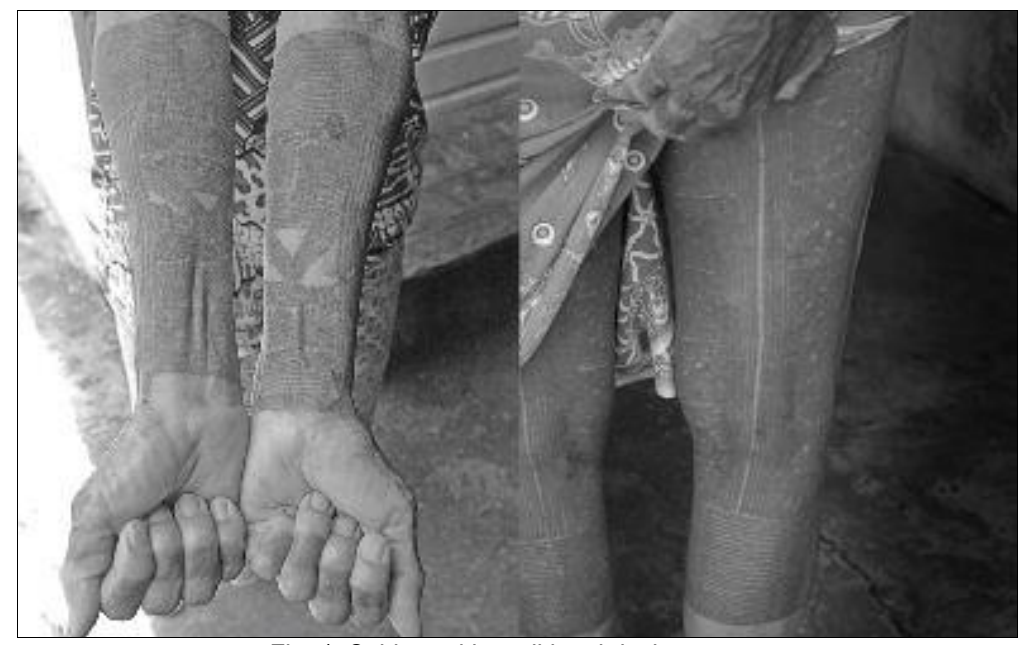

Fig. 1: Subject with traditional design tattoo.

However, this form of art had ceased to exist (Thomas, 1968). Thomas (1968) stated that tattooing among them was quickly disappearing and no longer practised. Lars Krutak (2006) also concurred with the view and further indicated that they had stopped tattooing 50 years ago. One main reason was the prohibition by the church to discourage such practice (Krutak, 2006). Some also thought that having a tattoo is no longer apt these days (Lim, 1991). Lim (1991) also reported that many of the tattoo artists who were the 'gatekeeper' of this art had passed away without protégée; taking their art with them. Consequently, today only older women have these traditional tattoos (Lim, 1991). They will be the last generation to have such tattoos, as illustrated in Fig. 1 and 2.

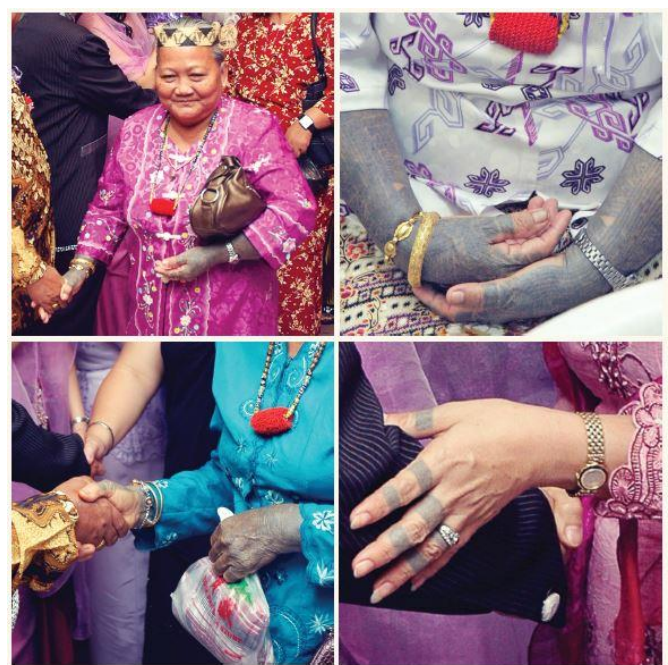

Fig. 2: Kayan women with traditional tattoos on their hands.

On the other hand, there is a need to enlighten the public regarding traditional tattoos so as differentiate them from modern tattoos. There are negative perceptions of traditional tattoo. If one has the tattoo, and the tattoo is deemed backward and primitive (Kalum (as cited in Puthankattil, 2013). Jeremy also stated that Malaysian in general often misunderstood tattoos and tend to associate them to gangsterism, cult, or satanism (Arp, 2012). Wong (as cited in Yuji, 2011) believes that while the tattoo is taboo for many, the practice to be re-evaluated and studied with more emphasis on origins and ontology. 


\subsection{Methodology}

In this research, a quantitative was favoured and heavily applied, where researchers conducted interviews to obtain information regarding the tattoo motifs. For sampling, due to the scarcity of Kayan women with the proper traditional tattoo, a snowball sampling was adopted where the initial interviewee, through their social contact, would nominate another one to be interviewed. Interviews conducted were unstructured interviews, where the direction of the conversation is determined by the respondent's initial reply to question (Collins, 2010). The crucial moment is because of the language barrier between interviewer and interviewees; and hearing complication of one interviewee due to old age. Therefore, during the interview, questions prepared changed based on the answers received. This procedure also allows interviewees to openly express their opinion more casually (Stuckey, 2013). A translator was used to overcome the language barrier.

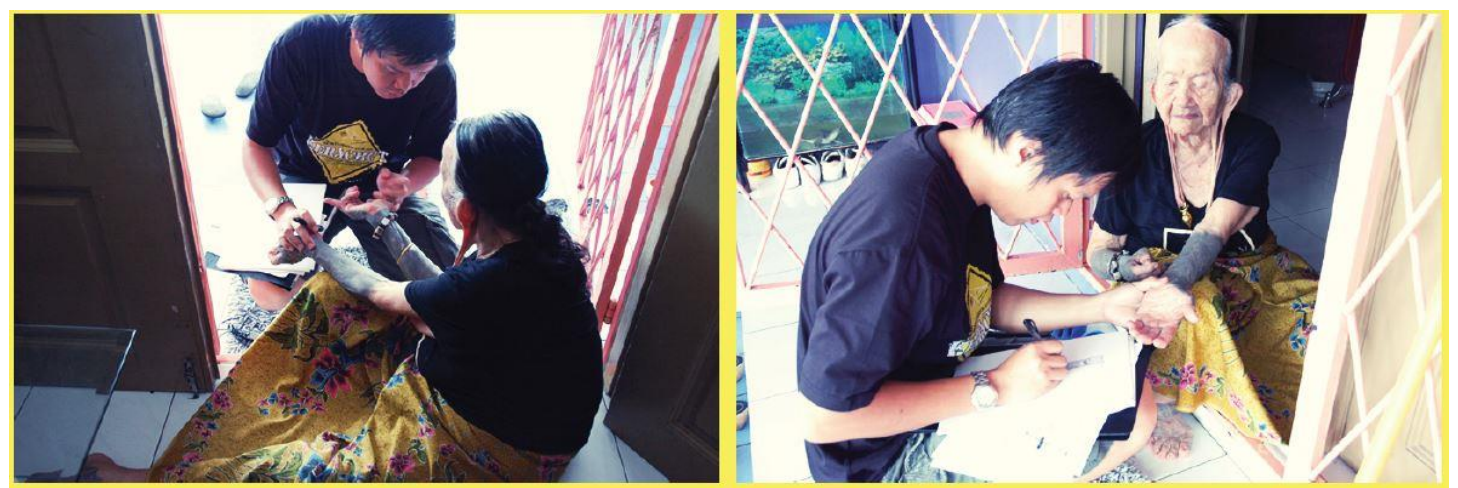

Fig. 3: Interviewing one of the subjects, Ubong Emang, at her residence.

Visual analysis was conducted to study the tattoo motifs obtained from the interviewees by de-constructing the motifs from the design. Hence, a research plan was established in the grounded-theory structure, which requires strict procedures when analysing data. Grounded theory is by itself, a method where data collection and the process of coding data coincide through taxonomies (Scott, 2009; Collins, 2010). It allows researchers to postpone the writing on literature review until the data has been collected (Collins, 2010). This is a way to generate fresh perspectives on topic being researched, especially on areas of social life. Therefore, the process taken by the researchers requires a series of the systematic investigation by establishing a set of taxonomy.

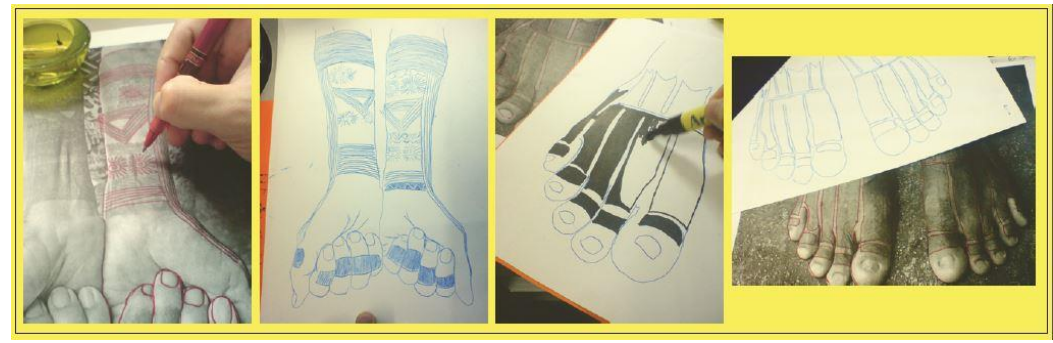

Fig. 4: Visual analysing the motifs by de-constructing the design.

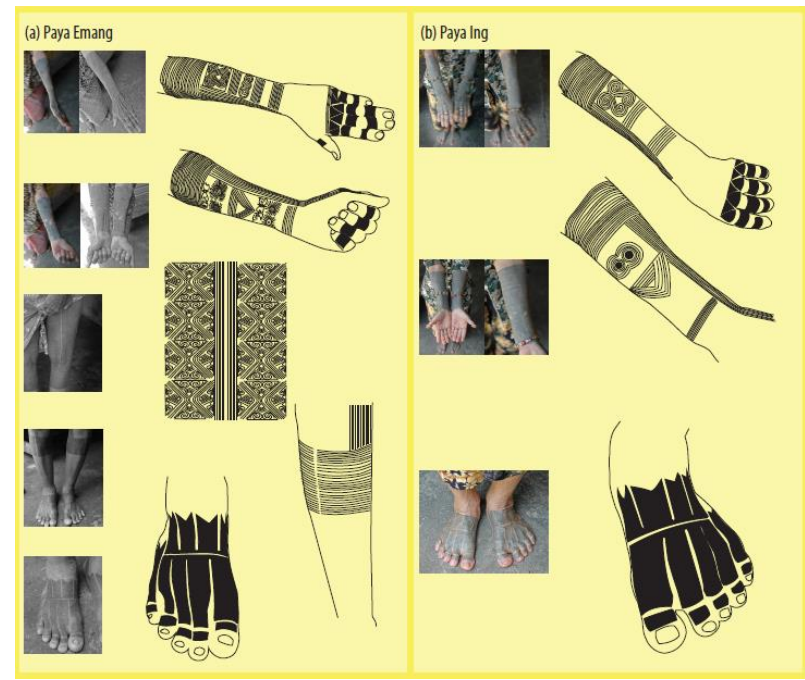

Fig. 5: Tattoo motifs were traced from photographs taken. 


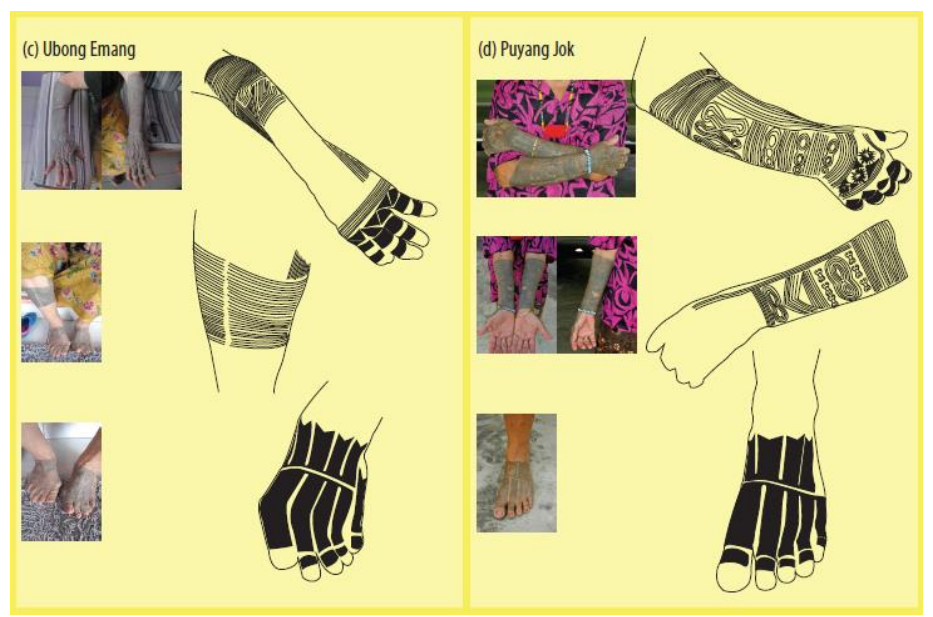

Fig. 6: Tattoo motifs were traced from photographs taken.

The next step taken was to categorise the samples according to parts of the body systematically and further de-constructed the tattoo into a smaller unit or motif. The aim is to look for similarity and difference among these motifs. This is also known as the preiconographic description (Collins, 2010).

\subsection{Findings}

The following are the results of the text-image-idea study, as shown in Table 1, 2 and 3. In Table 1, the wordings in native were translated to reveal the meanings. They were later analysed systematically through a structural-hermeneutical symbol analysis, in order to comprehend the image-text relationship as well as how they developed into tattoo motifs, as illustrated in Table 2 and 3.

Table 1: Translation and meanings

\begin{tabular}{|c|l|l|}
\hline No & Motif (in native language) & Meaning (in the English Language) \\
\hline 1 & Selungan (around the hands) & Band of rattan \\
\hline 2 & Song Irang & Bamboo shoots \\
\hline 3 & Usung Dian & The spike of durian fruit \\
\hline 4 & Tushun Tuva & Bundles of Tuba Root; or Derris Elliptica \\
\hline 5 & Kalong Pakok & Wild fern motif; or Pteridophyta \\
\hline 6 & Manok Wak & An owl; or eyes of an Owl \\
\hline 7 & Dulung Haruk & A bow of a boat \\
\hline 8 & Ji'an Manuk & A bird's beak \\
\hline 9 & Beliling Bulan (with two black spots) & Full moon, equinox \\
\hline 10 & Beliling Bulan (with 3 round spots) & Regular full moon without equinox \\
\hline 11 & Butit Halap & Belly of Halap fish; or Barbus Bramoides \\
\hline 12 & Akok & N/A \\
\hline 13 & Ida Pat & Four lines under \\
\hline 14 & Selingan (around the shin) & Band of rattan \\
\hline 15 & Tedek Danau & Muddy tattoo \\
\hline
\end{tabular}

In Table 1, the translation was done with the help of a translator and aided by cross-referencing with previous journals. Only motif no. Twelve could not be determined but was identified at an earlier study. Table 2 and 3 show images retrieved by utilising the translated words. In this process, only data with pictures could be processed; therefore, item 12, 13, and 14 could not be processed due to the absence of image reference. Table 4 is a semiotics analysis. 
Table 2: The motif, the image and the concept. (Source: Google Images)

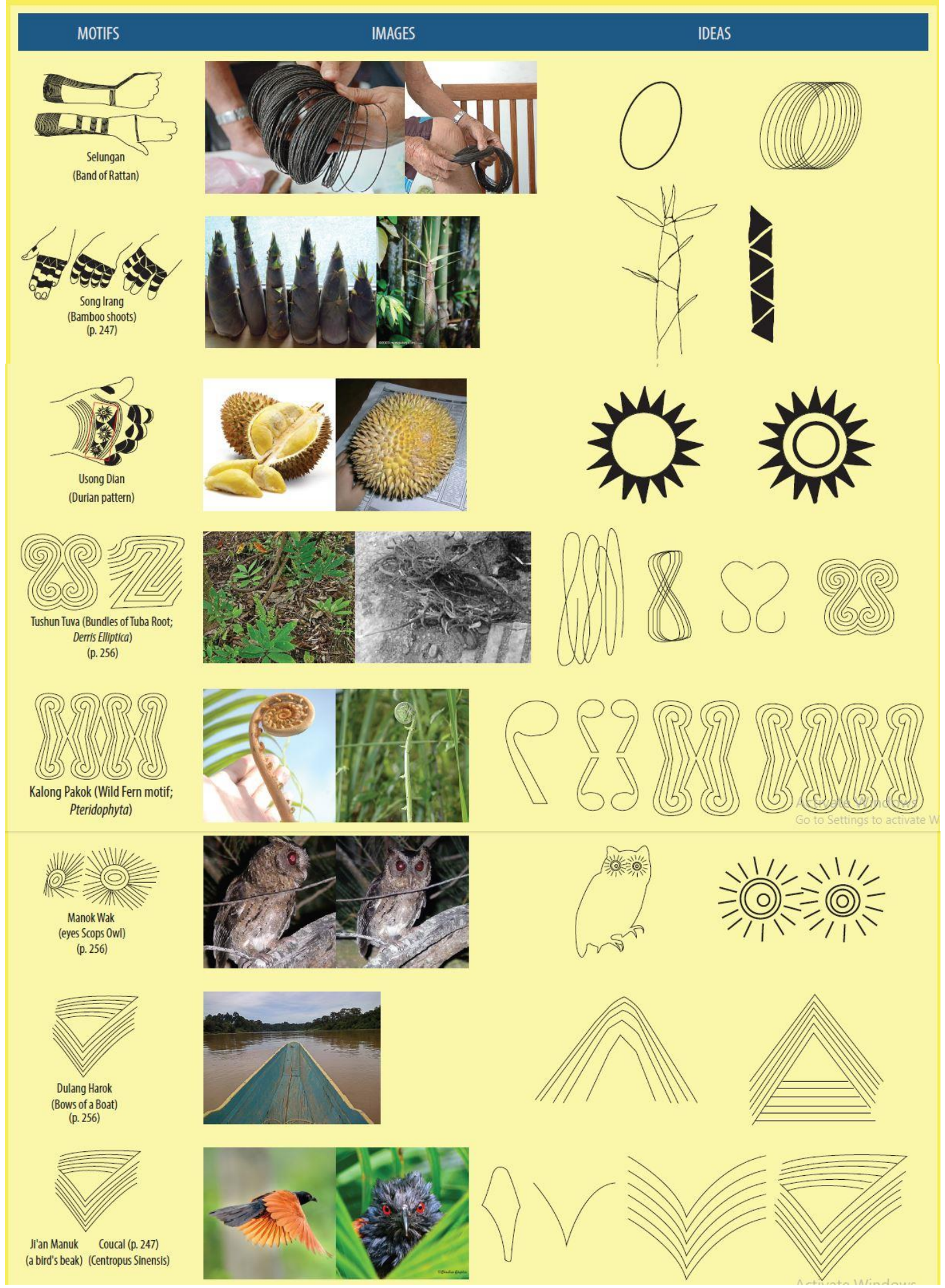


Table 3: The motif, the image and the concept. (Source: Google Images)

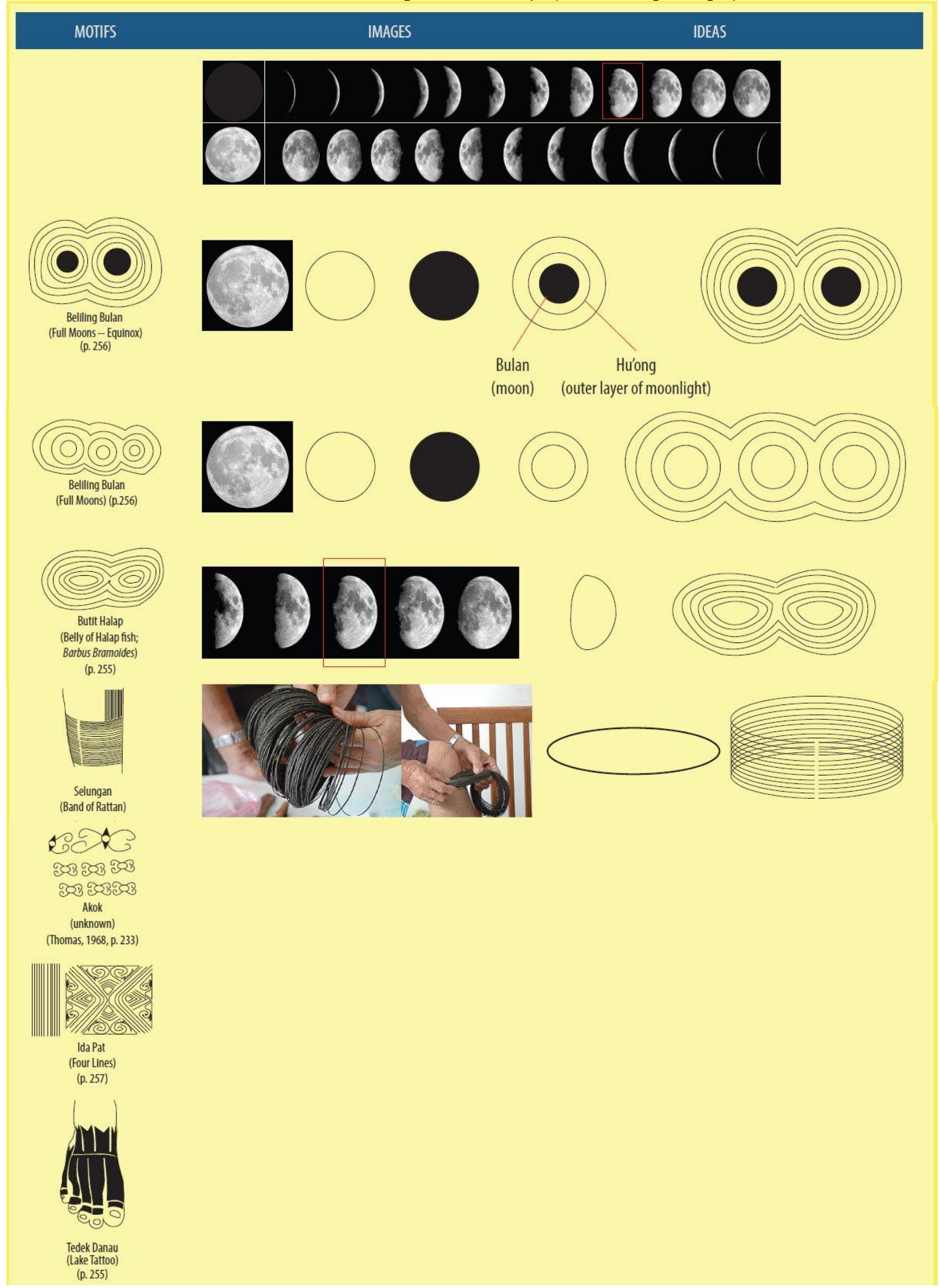


Table 4: The motifs and the significances

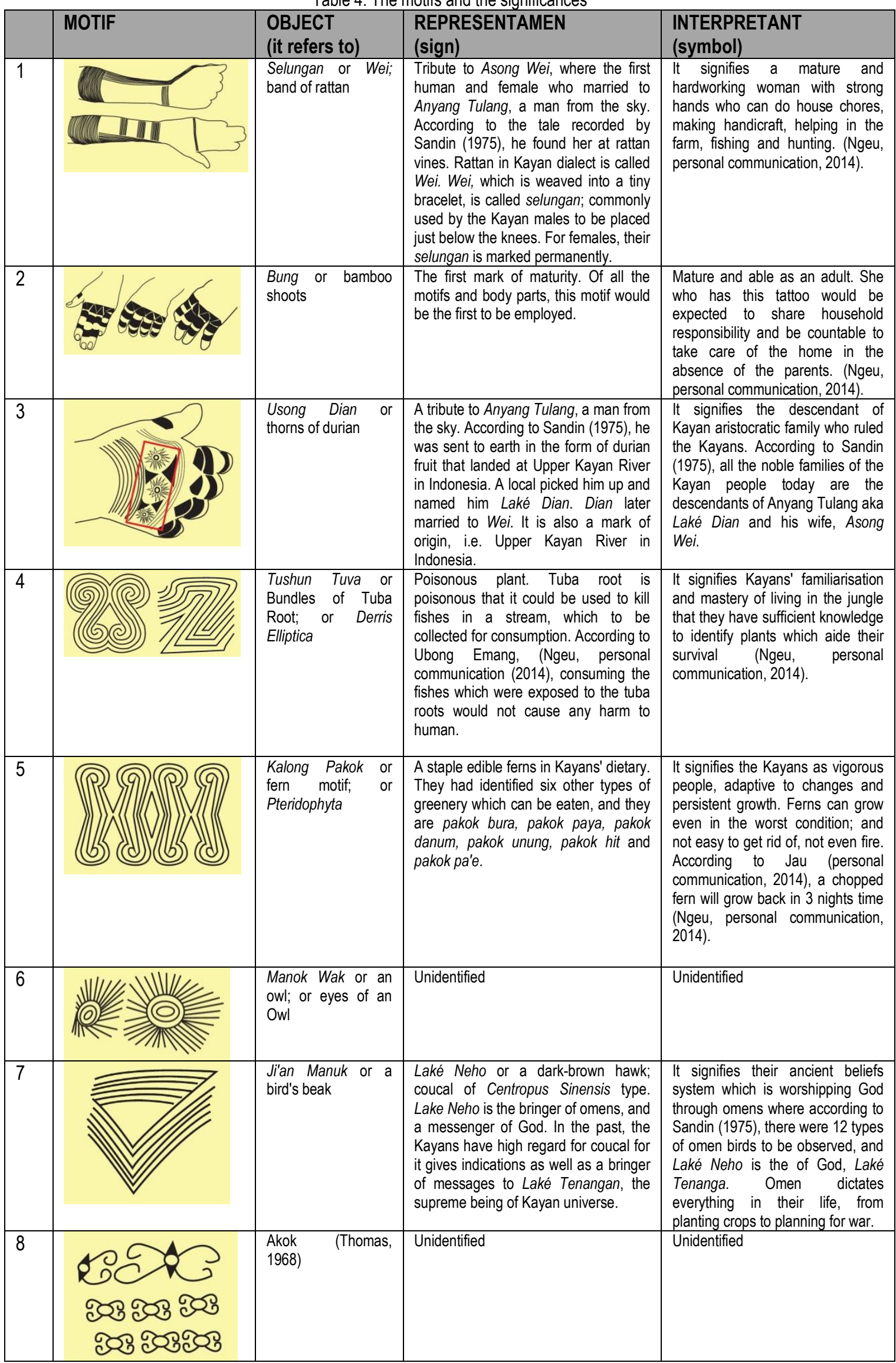




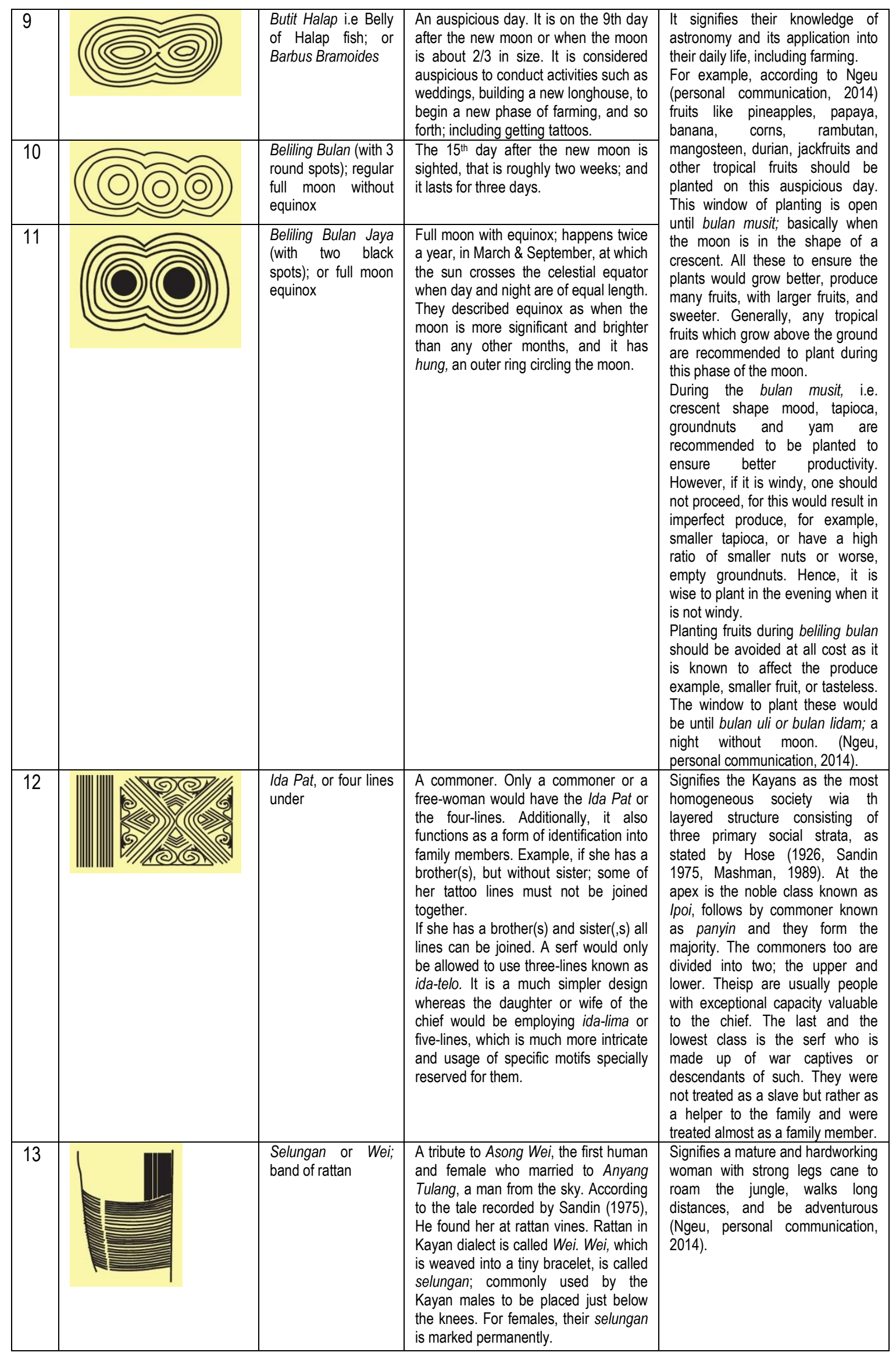




\begin{tabular}{|l|l|l|l|}
\hline 14 & $\begin{array}{l}\text { Tedek Danau, or } \\
\text { muddy tattoo. }\end{array}$ & Unidentified & \\
\hline
\end{tabular}

\subsection{Discussion}

The current collection of motifs obtained is slightly identical to some motifs derived by previous researchers, especially Hose and McDougall (1912), and Thomas (1968). This suggests some degree of consistency in term of the motifs among the Kayan women folks from Baram. Researchers find their journal very useful for cross-referencing as they published their papers with visual of the tattoo motifs, which is crucially important when investigating visual.

Referring to Table 4, motif selungan or wei (No.1 and No. 13) was identified by Hose and McDougall (1912) as just 'several lines' (p. 255, para 3:5). Thomas (1968) too documented a pair of hand tattoos but no discussion found regarding this motif. According to (Ngeu, personal communication, 2014), this motif is known as either selungan or wei. When wei is weaved into a tiny bracelet such as the one featured in Table 3, it is then called selungan. It is commonly used by the Kayan males to be placed just below the knees or arms. For females, the version is marked permanently in the form of the tattoo around the hands and just below the knee cap.

Song irang (No. 2) was mentioned by Hose (1912, p. 250) with no further information. However, the subject interviewed identified it as bung, which is, shoot. All four subjects interviewed stated that it is the mark of maturity, and it would be the first tattoo motif to be employed. This motif usually is on fingers and knuckles and rather than other parts of the body because it has to be visible to the public; signifying to the longhouse folks that she has matured. Therefore, this a very common motif among the Kayans and Kenyahs alike.

Hose and McDougall (1912, p. 249 - p. 266) described Usong dian (No. 3) as 'rosette or a star design', and they recorded that is derived from 'the eye in the dog pattern'. This is due to the fact known to both Hose and McDougall that the Kayans have high regards for dog and thus many of their handicraft's motifs were inspired by dog motif. According to interviewees (personal communication, 2014), it is called usong dian, which means, the spike of durian. This brought us to the writing of Sandin (1975) who had published a journal about the origin of Kayan peoples. Sandin mentioned that a prince named Dian came to earth from the sky and married a woman from the earth and the Kayan peoples were born. Hence, usong dian motif is a mark of remembrance of their origin.

Tushun tuba (No. 4) is actually a bundle of tuba roots. It was documented by Hose and McDougall (1912) and later by Thomas (1968). It has a few versions and visually speaking they all look slightly similar; basically, a bundle of angular lines except that some might have a distinctly human face. Hose and McDougall also mention about termed this degraded anthropomorphic for the human face is visible but almost unrecognisable. Based on samples obtained by researchers, they are a proper tuba root motif. The Kayans valued these roots as it is poisonous; which can be found growing wild in the wood along the riverbank. In the olden days, collected tuba roots would be used to catch fishes by releasing tuba's poison into the river. According to Ubong Emang, (personal communication (2014)), consuming fishes captured this way would not pose any harm to human. She explained that tuba-fishing is an old method of fishing and it had already been abandoned since the 70's or earlier when they realised that this method of fishing is not sustainable.

Kalong pakok or fern a new motif (No. 5), and this is probably a new motif; a much better aesthetics version from Thomas who first documented it in 1968. Thomas's copy of this motif is a bold stripe of line forming a reversed 'S' shape. This reversed 'S' should be distinguished from Hose and McDougall's copy (1912, p. 257-259), which has details surrounding the 'S' and it has the eye and a beak. It looks more like a dragon, as suggested by Thomas (1968) than a wild fern; while Hose and McDougall (1912) documented it as a hornbill design. It is certain that kalong pakok is fern motif (Ngeu, personal communication, 2014). The Kayans being a community residing deep in the Borneo jungle, their diets are mainly wild edible vegetation and as such are capable of finding food for survival and when it comes to edible ferns; they have identified six types of fern which can be eaten, and they are pakok bura, pakok paya, pakok danum, pakok unung, pakok hit and pakok pa'e (Ngeu, personal communication, 2014).

There is confusion with dulang harok and jian manok (No. 7) as both are identical but with different names. Hose and McDougall documented it as dulang harok or bow of a canoe (Hose and McDougall, 1912, p. 266, Plate 140, Fig. 1). Interviewee added that to her best knowledge of the Kayan language, the word dulang does not exist and added it might not even be a Kayan word; therefore, she dismissed the term used. She argued that bird's beak is more appropriate because in the ancient past the Kayans had a beliefs system which is based on omens represented by birds, and this was published by both Hose and McDougall (1912), Hose (1926), and Sandin (1975). Of all the birds in the omen system, dark brown coucal of Centropus Sinensis type is favoured. The Kayans named it Laké Neho, for it is believed to be the messenger to a supreme being of Kayan universe.

Motif No. 9, 10 and 11 are all inspired by moon shape and its phases known as butit halap, beliling bulan, and beliling bulan jaya respectively. Hose and McDougall's copy of these motifs are much clearer because they obtained them in the form of woodblock stamp (1912, p. 266, plate 140, item 1 and 2) known as klinge and therefore their copy of beliling bulan (No. 10) has perfect circle compare to researchers' copy. They described it as a 'band of concentric circles' and no further discussion about it. According to Ngeu 
(personal communication, 2014), it signifies full moon which lasts for three nights, appears typically on the 15th day after the new moon is sighted, that is roughly two weeks' time.

Another motif is called beliling bulan jaya (No. 11), and this has two black dots in the centre of the moon shapes. This signifies full moon equinox which happens twice a year, generally in March and September, at which the sun crosses the celestial equator when day and night are of equal length. They described equinox as when the moon is larger and brighter than any other months; and it has hung (umbrella), an outer ring circling the moon which is visible with naked eyes.

Butit halap (No. 9) which has an oval shape instead of circular; and it has yet to be documented before. The literal translation for it would be the 'belly of halap fish', a fish known in scientific as barbus bramoides. It is named so because the shape of the moon resembles the shape of the halap fish's belly. However, it was named so due to the absence of vocabulary to refer to oval shape; and so the only way to describe this phase of the moon is to adopt the shape of halap fish's belly. For the Kayans, this phase of the moon is deemed to be auspicious. It occurs on the 9th day after the new moon or when the moon is about $2 / 3$ in size. It is considered auspicious to conduct activities such as weddings, building a new longhouse, to begin a new phase of farming, and so forth; including getting tattoos.

Motifs No. 9, 10 and 11 indicate that the Kayans are very observance of the moon, especially so in agriculture. According to Ngeu (personal communication, 2014), fruits like pineapples, papaya, banana, corns, rambutan, mangosteen, durian, jackfruits and other tropical fruits should be planted on this auspicious day. This window of planting opportunity is open until bulan musit; basically when the moon is in the shape of a crescent. All these to ensure the plants would grow better, produce many fruits, with larger fruits, and sweeter. Generally, any tropical fruits which grow above the ground are recommended to plant during this phase of the moon. During the bulan musit, i.e. crescent shape mood, tapioca, groundnuts and yam are recommended to be planted to ensure better productivity. However, if it is windy, one should not proceed, for this would result in imperfect produce, example, smaller size tapioca, or have a high ratio of smaller nuts or worse, empty groundnuts. Planting fruits during beliling bulan should be avoided at all cost as it is known to affect the produce severely. The best time to plant these would be until bulan uli or bulan lidam; means night without the moon (Ngeu, personal communication, 2014).

Motif no. 12 is ida pat signifies social status, and for this particular motif, it is meant for a commoner. Only a commoner or a freewoman would have the ida pat, or the four-lines. Additionally, it also functions as a form of identification into family members. Example, if she has a brother(s), but without sister; some of her tattoo lines must not be joined together. If she has a brother(s) and sister(s) all tracks can be joined. A serf would only be allowed to use three-lines known as ida-telo. It is a much simpler design whereas the daughter or wife of the chief would be employing ida-lima or five-lines, which is much more intricate, and usage of specific motifs specially reserved for them. It goes to verify that the Kayans as the most homogeneous society with a stratified structure consisting of three main social strata, as stated by Hose (1926, Sandin 1975, Mashman 1989). At the apex is the noble class known as ipoi, follows by commoner known as panyin and they form the majority. The commoners too are divided into two; the upper and lower. The upper is usually people with exceptional capacity valuable to the chief. The last and the lowest class is the serf who is made up of war captives or descendants of such. They were not treated as a slave but rather as a helper to the family and were treated almost as a family member.

There are three motifs which researchers could not decode, and they are motif no. 6, 8, and 14 (Table 2), which are manuk wak, akok, and tedek danau, respectively. The interviewee stated that motif no. 6 is an owl (manuk wak) but could not recall why this particular bird was made into a tattoo. Furthermore, this bird is not one of the twelve omen birds discussed earlier. It would be interesting to know should this bird has significance to the life of the Kayans in the past. Motif no. 8, akok, is a similar motif documented by Thomas (1968); and none of the interviewees provides no clue to its importance. The same goes for tedek danau. The only discussion here is that this particular motif is ,prevalent and this is contrary to Hose and McDougall's remark that this motif is obsolete when they found out that Dr. Nieuwenhuis found this in the 1890s at Dutch East Indies (Hose \& McDougall, 1912; p. 255). Based on the samples collected, these motifs still very much exist.

Although this might be polysemic, the researchers attempt to make sense of the meanings as close as possible. It also helps us comprehend the idea behind each motif and its' significance. The outcomes reveal the connection between the motifs and their weltanschauung in the past, which have not been explored before.

\subsection{Limitations}

It is rare to find Kayan womenfolk with a complete tradition tattoo, and that itself is a huge hurdle. There is also the issue of visibility of the tattoo due to exposure to the sun and old age. Bear in mind that the womenfolk are still very active in agriculture and exposing to the scorching sun is a norm. Most of these people are living in longhouses deep in the Borneo jungle, and there is no proper road to get there. It is definitely risky to visit any Kayan longhouses due to the distance and the poor road condition.

\section{Conclusion and Recommendations}

The motifs are inspired by nature and they are highly stylised without losing the essence of the design from the original sources. Many motifs are floral and a few zoomorphic. This is a testament that they are living very close to nature and they had identified certain plants or animal which have significant influence in their life socially and their spiritual beliefs. Therefore, it is not an exaggeration to conclude that these tattoos are actually a form of coded messages recording tale of origin, social order, dietary, survival trick, their 
ancient beliefs system, as well as their understanding of the solar system and how different phases of the moon would affect their crops. All these were recorded into tattoo motifs to be passed down to the next generation.

The intention of this paper is not to revive the tattoo practice but to learn, understand and appreciate the ancient knowledge embedded with the motifs. The researchers agree with Thomas (1968) that many Kayans' beautiful designs exist only in the medium of tattoos. Perhaps, as Thomas suggested in 1968, these motifs could be a great source of inspiration for creating meaningful creative works in the future. It is recommended that further research in this topic should be encouraged to document and decode the other motifs, especially the anthropomorphic type which is absent in this research. It has to be done sooner rather than later as those who have these types of tattoos are in their 80 s.

\section{Acknowledgement}

Many thanks to those whom I had interviewed and photographed; they are Paya Emang, Ubong Emang, the late Paya Ing, and the late Puyang Jok. I would like to thank Universiti Teknologi MARA (UiTM) for their patronage as well.

\section{References}

Arp, R. (Ed.). (2012). Tattoos-Philosophy for everyone: I ink; therefore, I am (Vol. 57). John Wiley \& Sons.

Bibi Aminah Abdul Ghani, Dit T. J., Venkatasawmy, R. (2009). The Orang Ulu: Kayan. Pustaka Sarawak. Retrieve from http://pustaka-sarawak.com Collins, H. (2010). Creative Research: The theory and practice of research for the creative industries. Switzerland: AVA Publishing, 41, 134, 140-141.

Hall, S. (2012). This Means This, This Means That. A user's Guide to Semiotics (2nd ed.). China: Laurence King Publishing, 22.

Hose, C., \& McDougall, W. (1912). Pagan Tribes of Borneo: Vol. 1. London: Frank Cass, 246-249, 251-252.

Hose, C. (1926). Natural Man: A Record from Borneo. London: Macmillan, 33, 49-50, 185, 222, 252-255, 261-276.

Jalong, J. (2001). Kalong: Seni Motif Tradisi Orang Ulu. Kuala Lumpur: Kementerian Kebudayaan Kesenian dan Perlancongan Malaysia.

Krutak, L. (2006a). Torches for the Afterlife: Women Tattoo Artists of Northern Borneo. Lars Krutak: Tattoo Anthropologist. Retrieved from http://www.larskrutak.com Krutak, L. (2013b, August). As Worlds Divide: A Mentawai Documentary. Lars Krutak: Tattoo Anthropologist. Retrieved from http://larskrutak.com

Lim, A. N. (1991, December). Tracing tattoos in Sarawak. Sarawak Gazette, Vol. CXVIII, 46-51.

Mashman, V. (1989). Ethnic arts and society - An Orang Ulu study. Sarawak Museum Journal, Vol. XL, 215-227.

Marudi District Office. (2012). Profile Daerah Marudi, Baram: 2012. Retrieved from http://marudido.sarawak.gov.my/

Nobel, I; \& Bestley, R. (2005). Visual Research: An Introduction to Research Methodology in Graphic Design. Switzerland: AVA Publishing, 92.

Ongie, W. B. (2012, September 19). Baram folk asked to preserve cultural and arts heritage. The Borneo Post. Retrieved from http://theborneopost.com

Payne, J., Cubitt, G., Lau, D., \& Langub, J. (1994). This is Borneo. United Kingdom: New Holland.

Puthankattil, V. (2013, September 21). The ink of life. The Heat, 14.

Sandin, B. (1975). The traditional folklores of the Kayan of Upper Rejang. Sarawak Museum Journal, Vol. XXIII, 53-79.

Scott, H. (2009). What is Grounded Theory? Grounded Theory Online. Retrieve from http://groundedtheoryonline.com

Stuckey, H. L. (2013). Three types of interviews: Qualitative research methods in social health. Journal of Social Health and Diabetes, 1(02), 056-059.

Thomas, S. (1968). Women's tattoo of the Upper Rejang. Sarawak Museum Journal, Vol. XVI, 209-234.

Types of Interviews. (2013). Student Success Centre. Retrieved from http://success.uwo.ca

Ulrich. W. (2011). Towards a Taxonomy of Research Practice [Weblog post]. Ulrich's Bimonthly. Retrieved from http:/wulrich.com

Yuji. (2012, January 10). Advocating the art of tattoo. The Star. Retrieved from http://thestar.com.my/

Yussop, Y. (2012, November 28). Call for another state seat in Belaga. The Borneo Post. Retrieved from http://theborneopost.com 